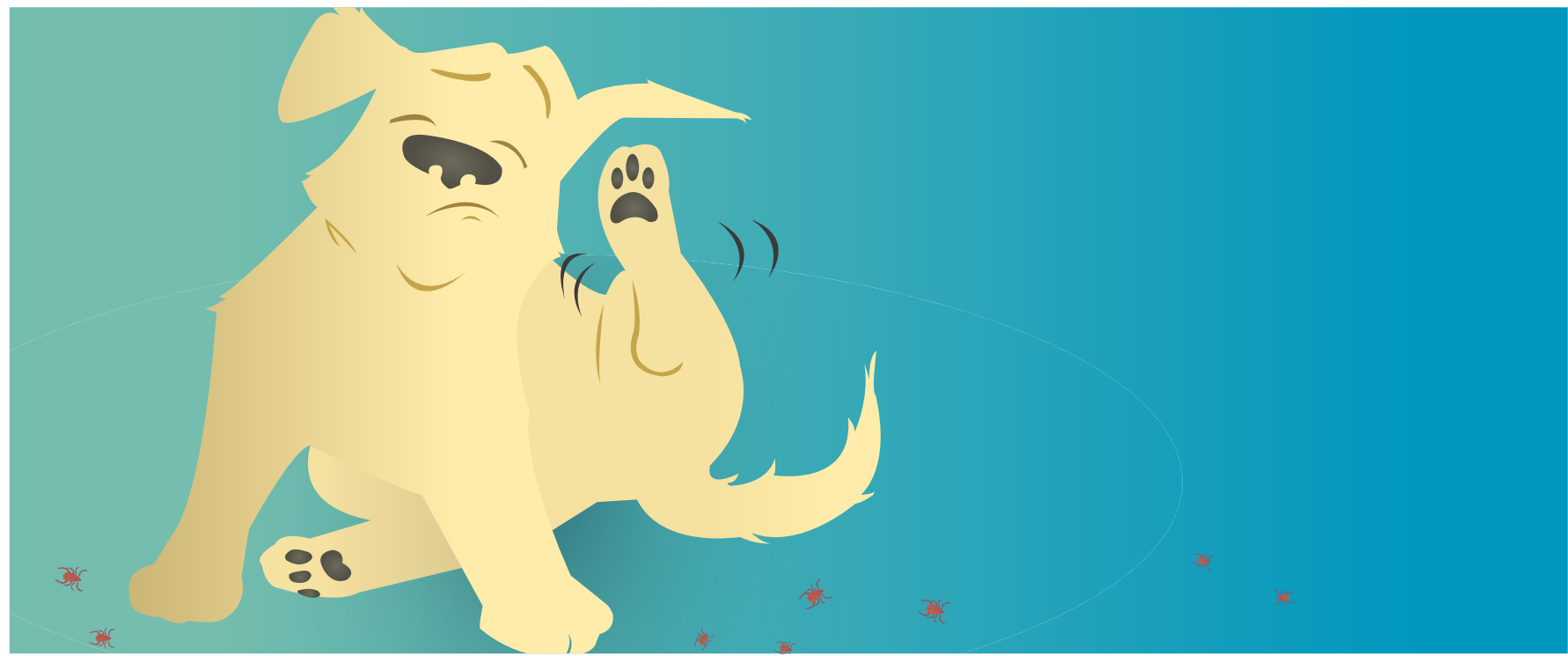

\title{
WHAT MAKES YOUR DOG ITCH? MAYBE IT IS THE KENNEL TICK!
}

\section{Joana Ferrolho*, Gustavo S. Sanches, Joana Couto, Sandra Antunes and Ana Domingos}

Global Health and Tropical Medicine - Instituto de Higiene e Medicina Tropical, Universidade Nova de Lisboa (GHTM-IHMT-UNL), Lisbon, Portugal

\section{REVIEWED BY: \\ PITTSBURGH GIFTED \\ CENTER 10-11 YEARS OLD}

Once upon a time, in a backyard not very far from you, lived a dog named Rex with long fluffy and shiny hair. Rex really loved to play outside, especially with his best friend and owner Jack, a nine-year-old boy. On a perfect spring day, when it was not too cold or too hot, Jack and Rex went for a walk in a green park close by, and when they returned home Jack noticed that his loyal friend was very itchy and was scratching his ear a lot. His first thought was as follows: "Well, there must be some dirt in his ear! After so much rolling on the grass it is normal." A few days later Jack saw that Rex was very unhappy and started wondering what was happening. He called his mother quickly and they both rushed to see Rex. "Mommy what's that on Rex's ear? It seems like a wart! Is Rex sick?" Then his mother said "Hopefully not! You know Jack, these little things are parasites called ticks and they can make Rex itch and feel uncomfortable. I am sure that if you learn more about such small and incredible creatures, you will be amazed because there is more to them than meets the eye..." 


\section{ZOOLOGIST}

A scientist who studies animals.

\section{GENETIC}

MATERIAL

Material used to store inherited information in the nucleus or mitochondria of a cell.

\section{A BIT OF HISTORY ABOUT THE KENNEL TICK}

Pierre Latreille, a French zoologist, was the first to describe the kennel tick in 1806. Some decades later, the German scientist Carl Ludwig Koch studied these ticks too, and based on some of their characteristics he gave the scientific name Rhipicephalus sanguineus to this tick species. These ticks still have the same scientific name today [1, 2]. Because houses and kennels where the dogs live can frequently become infested, often with very high numbers of ticks, this tick species is often referred to as the kennel tick.

\section{WHERE IN THE WORLD CAN WE FIND THIS TICK?}

The kennel tick is the most widespread tick in the world, but it is especially common in tropical and subtropical regions. In cooler regions, these ticks are more active from late spring to early autumn; however, in tropical and subtropical areas they are active over the entire year [3].

\section{WHAT DOES THIS TICK LOOK LIKE?}

Generally, kennel ticks are small, between 3 and $4.5 \mathrm{~mm}$ in length, with an elongated body and red-brown in color (Figure 1) [1].

\section{DO YOU THINK THAT ALL THE TICKS WITH THESE CHARACTERISTICS ARE THE KENNEL TICK?}

Until recently, we would have called all the brown dog ticks with the structural characteristics shown in Figure 1 kennel ticks. Currently, studies analyzing the genetic material of these ticks have shown that there are more than one species under the name $R$. sanguineus $[2,4]$.

\section{HOW DO KENNEL TICKS COMPARE TO OTHER TICKS, SUCH AS THOSE FOUND ON DEER? DO THEY HAVE SAME SIZE AND THE SAME NUMBER OF LIFE STAGES?}

Normally, the ticks found on larger animals, like deer and cows, are a different species of ticks than those found on dogs. Because of this, ticks that bite larger animals can look a little different than kennel ticks, even though they are pretty much the same size as the kennel tick. That is why we must look at ticks under a magnifying glass to identify the species. The number of life stages is the same for all ticks: egg, larvae, nymph, and adult. These stages are shown in Figure 2 and will be described below. 


\section{FIGURE 1}

The body structure of the kennel tick, as seen through a powerful microscope.

A. Dorsal and B. ventral view of an adult female. C. Dorsal and D. ventral view of an adult male.

\section{DORSAL VIEW}

View of the back or upper surface of an organism.

\section{VENTRAL VIEW}

View of the front or belly of an organism.

\section{FIGURE 2}

The kennel tick life cycle. The magnifying glass shows a close-up of what is happening on the dog's ear (brown background) and on the ground (white background). The dotted lines (- - ) show when the different developmental stages of the tick leave the host.
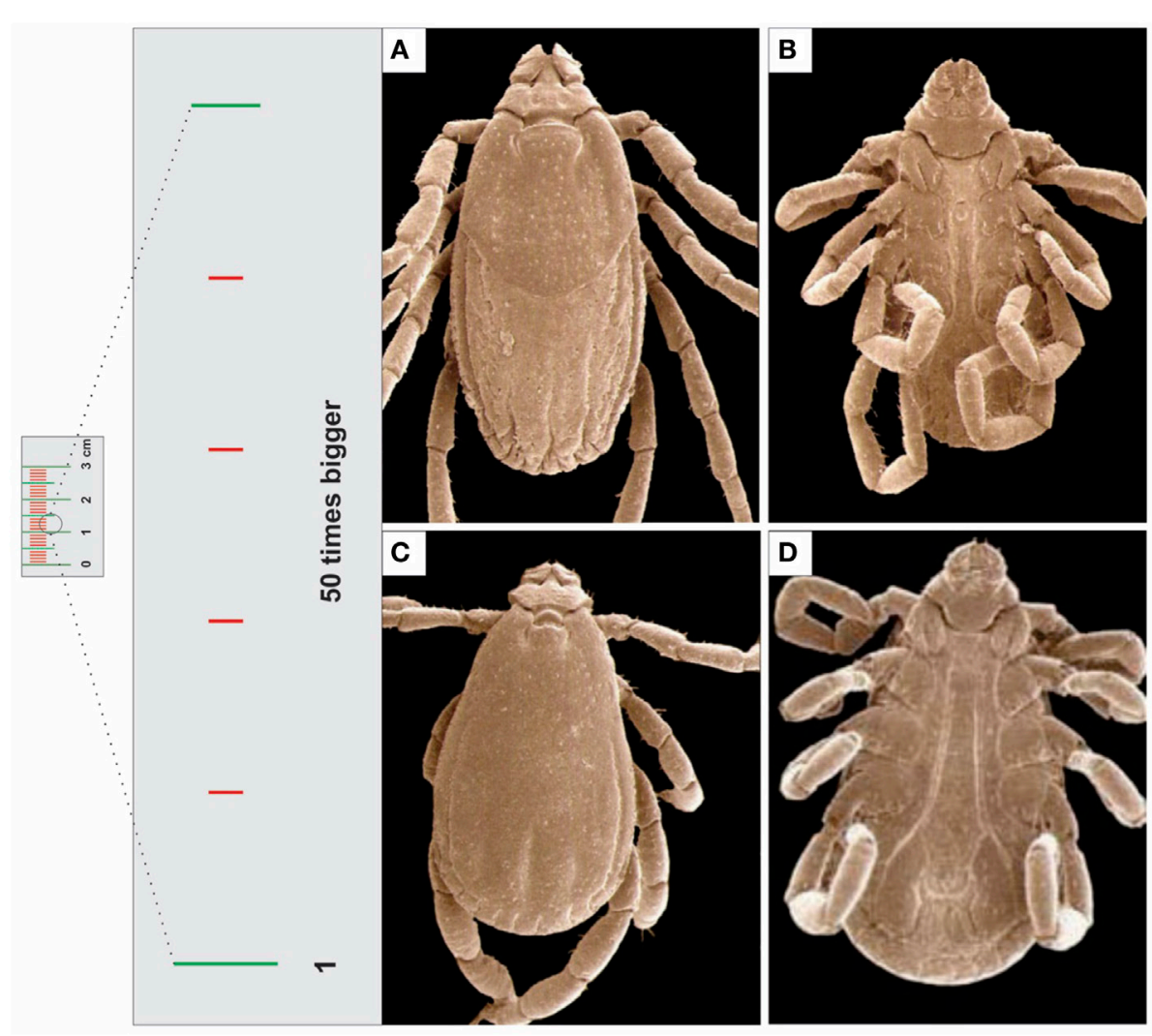

FIGURE

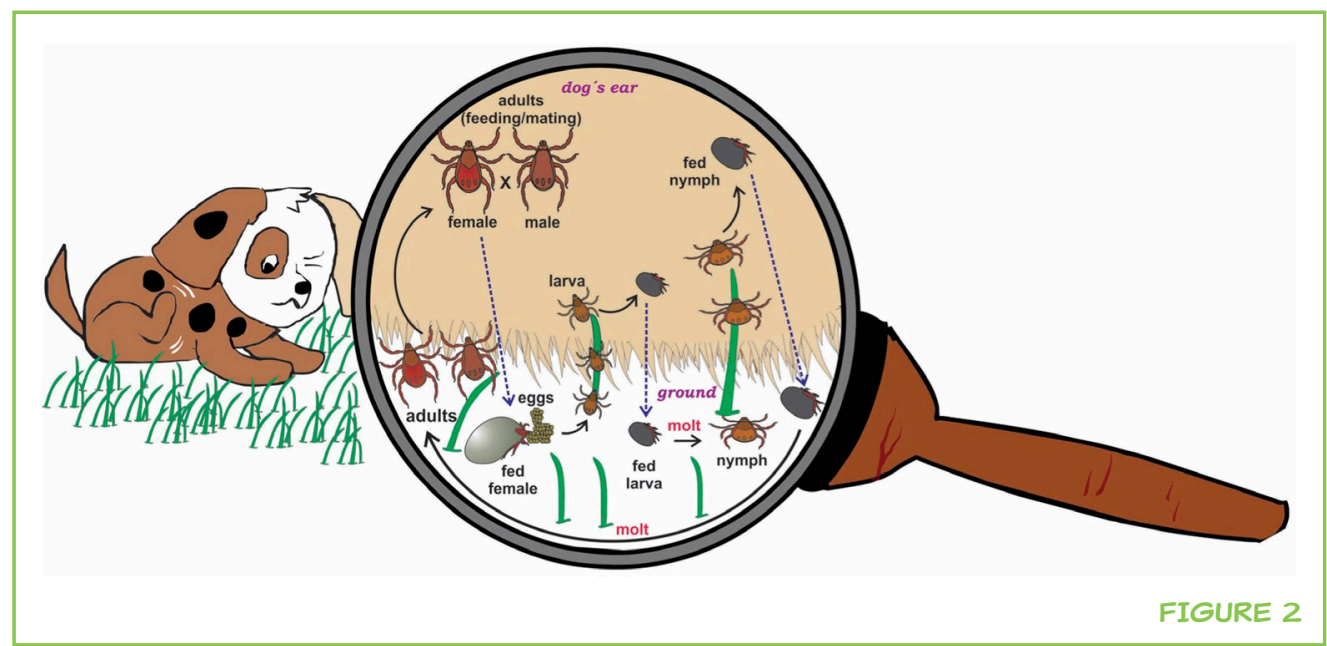

\section{WHO CAN HOST THE KENNEL TICK?}

Kennel ticks prefer dogs as their companions and restaurants, known as hosts, in urban and rural areas. But in the absence of dogs, and because they really need to eat, kennel ticks can alternatively feed on other tame and wild animals [3]. Some examples of alternative hosts are rodents and other small animals, such as rabbits, cats, pigeons, wolves, foxes, and sometimes people. 


\section{FROM THE EGG TO THE ADULT STAGE:}

THE TICK LIFE CYCLE

This tick undergoes four stages of development: egg, larva (with only three pairs of legs), nymph, and adult (with four pairs of legs). To complete their development they require blood meals, once as a larva, once as a nymph, and as an adult. These developmental stages are shown in Figure 2. During the feeding process, an adult female tick is able to ingest around half a milliliter of blood, which corresponds to approximately 100 times the tick's weight, and because of this females after feeding are called "engorged females" [5]. Adult females need more food than adult males because a lot of energy and nutrients are required to produce the eggs. Adult males do not need that much energy, so they ingest less food and consequently do not increase their body size very much. After they finish feeding, the engorged adult females leave the animal and lay a large batch of eggs in a sheltered place, like the cracks or crevices in houses or outbuildings. Each female lays approximately 4,000 eggs and then she dies. After a while, the larvae hatch from the eggs and begin to search for a host so that they can have a blood meal. When they are full of food the larvae leave the host and molt, which means they change into the next stage, called nymphs. As nymphs, they feed again on a host, detaching when they are done feeding, and molt again into adult males and females. Then, the adults will also search for a host to feed on. On the host's body, the male and female mate to create the next generation of ticks (Figure 2). When conditions are right, the whole life cycle can be completed in just over 2 months [1].

\section{ARE KENNEL TICKS DANGEROUS FOR HUMANS AND ANIMALS?}

Ticks not only cause direct damage and irritation to animal or human skin due to the attachment of their mouthparts when they feed on the host's blood but they are also dangerous because they can carry in their bodies several types of disease-causing organisms, such as viruses, small worms, and bacteria. The kennel tick can transmit a bacterium in its saliva that can make dogs very sick. Dogs with this disease show a loss of appetite and energy, fever, sadness, and have very pale gums.

\section{DO TICKS SUFFER FROM THE DISEASES CAUSED BY THE ORGANISMS THEY CARRY?}

No, they carry the disease-causing organisms without suffering diseases themselves, and the ticks transmit the organisms to animals and humans when they feed on them. This is the reason why ticks are great vehicles for the disease-causing organisms. 


\section{HOW CAN I PREVENT MY DOG FROM GETTING TICKS AND IF I FIND ONE HOW CAN I REMOVE IT?}

Controlling the tick population outdoors is difficult, so the best way to prevent kennel ticks from attaching to your dog is to use tick-repelling products. These products can be in the form of sprays or liquids that you can apply to your dog's body or can be in the form of a special collar that your dog can wear. These products have one or more substances that, once in contact with the animal's skin, will be absorbed and spread through the blood stream. Then, when the tick is feeding on the dog, it will ingest the blood with these poisonous substances and the tick will die. Some ways of controlling ticks in your garden include the sealing of cracks and crevices where ticks can lay eggs or removing or cutting down high or dense grass and weeds [6]. But remember, not only ticks can make your dog itch. There are other parasites, like fleas, that also like to use your dog as a restaurant for a good meal!

How do you remove a tick from an animal or a human? Use fine-tipped tweezers to grasp the tick and pull it upwards with steady pressure. Never twist or jerk the tick. After removing the tick, clean the bite area and your hands with alcohol or soap and water. Dispose the tick by submerging it in alcohol in a closed container or flushing it down the toilet.

\section{CONCLUSION}

After reading all this information, you will be able to explain to Jack what Rex might have that makes him itch so much. Also, you will be able to suggest what to do when a tick is found on a dog, for example, that is important to act in the prevention applying products or collars with antitick products and/or remove the ticks. Jack's mother removed the tick as we described above and bought him a new antiectoparasite collar in the pharmacy. Rex did not show signs of any of the illnesses caused by the microorganisms that ticks can transmit. If you ever suspect that a dog is sick take it to your nearest veterinary surgeon.

\section{REFERENCES}

1. Walker, A. R., Bouattour, A., Camicas, J. L., Estrada-Pena, A., Horak, I. G., Latif, A. A., et al. 2003. Ticks of Domestic Animals in Africa: A Guide to Identification of Species. Edinburgh: Bioscience Reports, 74-221.

2. Nava, S., Estrada-pena, A., Petney, T., Beati, L., Labruna, M. B., Szabo, M. P., et al. 2015. The taxonomic status of Rhipicephalus sanguineus (Latreille, 1806). Vet. Parasitol. 208:2-8. doi:10.1016/j.vetpar.2014.12.021

3. Dantas-Torres, F. 2010. Biology and ecology of the brown dog tick, Rhipicephalus sanguineus. Parasit. Vectors 3:26. doi:10.1186/1756-3305-3-26 
4. Dantas-Torres, F., Latrofa, M. S., Annoscia, G., Giannelli, A., Parisi, A., and Otranto, D. 2013. Morphological and genetic diversity of Rhipicephalus sanguineus sensu lato from the New and Old Worlds. Parasit. Vectors 6:213. doi:10.1186/ 1756-3305-6-213

5. Koch, H. G., and Sauer, J. R. 1984. Quantity of blood ingested by four species of hard ticks (Acari: Ixodidae) fed on domestic dogs. Ann. Entomol. Soc. Am. 77:142-6. doi:10.1093/aesa/77.2.142

6. Dantas-Torres, F. 2008. The brown dog tick, Rhipicephalus sanguineus (Latreille, 1806) (Acari: Ixodidae): from taxonomy to control. Vet. Parasitol. 152:173-85. doi:10.1016/j.vetpar.2007.12.030

SUBMITTED: 03 March 2017; ACCEPTED: 07 June 2017; PUBLISHED ONLINE: 26 June 2017.

EDITED BY: Fulvio D'Acquisto, Queen Mary University of London, United Kingdom CITATION: Ferrolho J, Sanches GS, Couto J, Antunes S and Domingos A (2017) What Makes Your Dog Itch? Maybe It Is the Kennel Tick! Front. Young Minds 5:28. doi:10.3389/ frym.2017.00028

CONFLICT OF INTEREST STATEMENT: The authors declare that the research was conducted in the absence of any commercial or financial relationships that could be construed as a potential conflict of interest.

COPYRIGHT @ 2017 Ferrolho, Sanches, Couto, Antunes and Domingos. This is an open-access article distributed under the terms of the Creative Commons Attribution License (CC BY). The use, distribution or reproduction in other forums is permitted, provided the original author(s) or licensor are credited and that the original publication in this journal is cited, in accordance with accepted academic practice. No use, distribution or reproduction is permitted which does not comply with these terms.

\section{REVIEWED BY}

\section{PITTSBURGH GIFTED CENTER, $\|$ YEARS OLD}

We are a group of fifth and sixth grade students who LOVE science! Our school is part of the Pittsburgh Public School system. The name of our class is Toying with Science. In this class, we use toys and the scientific method to solve problems and learn about concepts of physical science.

\section{AUTHORS}

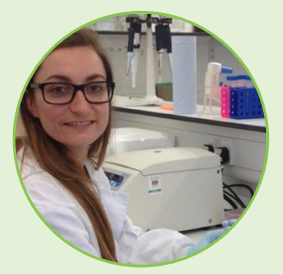

\section{JOANA FERROLHO}

Joana Ferrolho is a Veterinary Surgeon doing a $\mathrm{PhD}$ in Parasitology at Institute of Hygiene and Tropical Medicine in Lisbon, Portugal. Her PhD is about discovering new molecules to use in vaccines against ticks and tick transmitted pathogens. After work, Joana enjoys spending time with her little son, read books, and play with her dogs. *joana.ferrolho@ihmt. unl.pt 


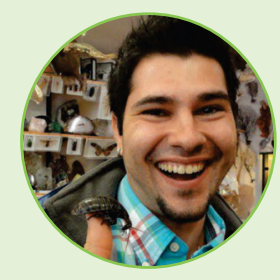

\section{GUSTAVO S. SANCHESSERON}

Gustavo Seron Sanches is a Biologist currently working as a Postdoc at Institute of Hygiene and Tropical Medicine in Lisbon, Portugal. His work involves the characterization of different strains of the "kennel tick" and to find the differences between their molecules. During Gustavo's free time he likes to exercise, walk his dog, and travel around the world.
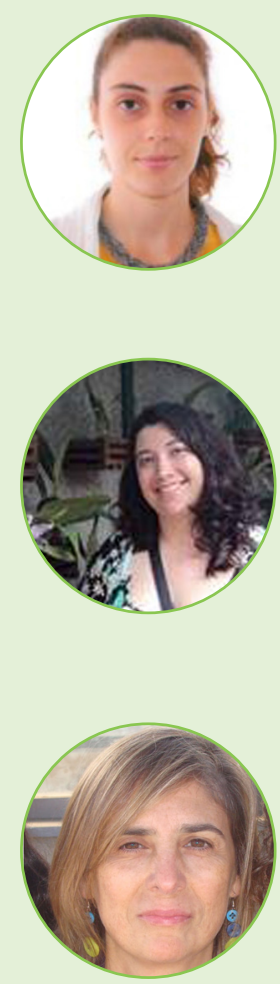

\section{JOANA COUTO}

Joana Couto is a Biologist doing a PhD in Molecular and Cellular Biology at Institute of Hygiene and Tropical Medicine in Lisbon, Portugal. Her studies are focused on the interactions between ticks and pathogens using tick cells, to identify molecules to block pathogen transmission, or to control tick infestation and use them to design a vaccine. Joana loves to play with animals and go to the cinema.

\section{SANDRA ANTUNES}

Sandra Antunes is a Biologist currently working as a Postdoc at Institute of Hygiene and Tropical Medicine in Lisbon, Portugal. She is working with tick species that affect sheep and cattle, investigating molecules that act during the tick's blood meal and when the tick has a pathogen in its organism. During her free time, Sandra likes to spend time with her two sons, to watch TV series, and to play with her cat.

\section{ANA DOMINGOS}

Ana Domingos is a Principal Investigator, working at Institute of Hygiene and Tropical Medicine in Lisbon, Portugal. Ana's main research interest includes the development of vaccines against ticks and tick transmitted pathogens. Currently, she supervises several MSc and PhD students and Postdocs who work in different projects. During her free time, Ana likes reading, going to plays, and practicing yoga. 